\title{
Loading members with investment choice
}

Received (in revised form): 10th May, 1999

\section{Anthony Asher}

is Professor of Actuarial Science at Wits University in Johannesburg, and has an actuarial interest in investment. He is Chairman of trustees of the University's Retirement Fund, the board of the Community Growth Fund Management Company, and a member of the Ministerial Advisory Committee on Pension Funds.

\begin{abstract}
This paper discusses why South African retirement funds might not respond to requests for member investment choice in defined contribution schemes. A significant minority of retirement fund members might want a less risky investment policy than the average. However, no really secure investments are available in South Africa. Equities, though, have given significantly greater returns than other classes, and with less risk when measured over longer periods. The major question facing retirement fund investors, therefore, is the continued existence of this equity premium. In the light of uncertainty as to its future, it is suggested that investment choice is unlikely to be of much value to members as it overloads them with worry and expense.
\end{abstract}

Keywords: investment, equity premium; member choice; South Africa

\section{Introduction}

Retirement funds accumulate assets for their members' retirement. Like all investors, they face the challenge of obtaining the best possible returns consistent with risks acceptable to their membership. The current reality is that there are no low-risk assets available in the South African market.

Fixed interest investments are subject to high rates of tax (varying from 25 per cent tax for retirement funds to the 45 per cent top individual marginal rate for South African residents, although some foreign investors do not currently pay tax). With inflation currently over 8 per cent interest rates of 14 per cent therefore, offer a net return somewhat lower than inflation to higher income earners. Even lower-rate taxpayers face the real, if remote, possibility of a future populist government devaluing the currency, as well as risks of default. Zimbabwe, to the north, while having a much smaller and less diverse and developed economy, provides an uncomfortable example of annual inflation over 40 per cent.

Current market rates are instructive, being approximately:

OECD government gilt rates $5 \%$

Risk of South African government default $+4 \%$

South Africa government OECD currency rates $\quad 9 \%$ Expected inflation differential $\quad+5 \%$ Current SA government rand rate 14\%

Investments in property and equities offers some protection in the long run against inflation, but are more volatile in the short run and are also subject to total loss. Andrew's ${ }^{1}$ calculations show that 
the average returns from 20 years of contributions, finishing at the end of each year from 1979 to 1993 in a mixed portfolio of 70 per cent equity and 30 per cent fixed interest, varied from a real return of 2 per cent to one of 7 per cent.

International investments offer some protection against local political and inflation risks, but are subject to currency fluctuations. As the rand is probably some 25 per cent undervalued on a purchasing power parity basis, a sustained rise is not improbable and would lead to significant losses on overseas holdings.

The government would do much to help risk averse local investors if it were to introduce inflation-linked stocks (not to mention the reduction in its annual borrowing requirement), but an obstinate complacency in the Finance Department and Reserve Bank has thus far prevented such a development.

\section{The members' risk aversion}

\section{Utility functions}

How does one create investment portfolios in this situation? If, as is generally accepted, one has to balance additional returns on investment against additional risk, then the question will depend on each member's trade-off between the two.

Such a balance can be described as a person's 'utility function'. This is the relationship between changes in wealth and changes 'utility', or enjoyment of the change. A person who is risk neutral (who does not mind taking risks) has a utility function that can be represented as a straight line on a graph. Each new unit of wealth gives rise to the same satisfaction as any other. Risk-averse people have utility functions that are concave - each additional unit of wealth is worth less than the previous, so they will not risk existing wealth to get more. Is it possible to construct utility functions for people?

\section{A local study}

Retirement funds accumulate assets for their members' retirement, and so the question of risk faces pensioners most acutely. The active members have only their imaginations and some anecdotal evidence as to what it means to be a pensioner.

What are the feelings of pensioners about financial risks and security? Over the past three years, third year Actuarial Science students at the University of the Witwatersrand, have each been given a project during their mid-year vacation to interview some 15 individuals, including five pensioners, about their attitudes to insurance and pensions. Some of the questions were designed to give some insight into common attitudes to risk.

No effort has been made to ensure that these pensioners are representative of the entire population. The main obstacle to achieving a representative sample is the internal migration of people over their lifetimes. The 1996 census shows that almost a quarter of the population between the working ages of 25 and 45 live in Gauteng province, but that the fraction is less than a sixth for those under five or over 70. The pattern is of migration of working people to the industrial heartland, but then of retirement to the coast in respect of wealthier whites, or to rural homelands in respect of black people. A thorough investigation would have to follow these patterns of migration very carefully.

These interviews do, however, provide some evidence as to the different perspectives on risk held by South African pensioners. Some $1.83 \mathrm{~m}$ of the 2.15 South African pensioners draw old-age assistance, which has been 
Table 1

\begin{tabular}{|c|c|c|c|c|}
\hline \multirow[b]{2}{*}{ State pensioners: } & \multicolumn{2}{|c|}{ Extra R100 } & \multicolumn{2}{|c|}{ R100 Less } \\
\hline & Save it & 10 & Spend less & 8 \\
\hline & Spend it & 9 & $\begin{array}{l}\text { Save less } \\
\text { Spend less }\end{array}$ & $\begin{array}{l}2 \\
9\end{array}$ \\
\hline & Give away & 11 & Spend less & 9 \\
\hline & & & Less giving & 1 \\
\hline & & & Family help & 1 \\
\hline \multirow{14}{*}{ All pensioners: } & Save it & 49 & Spend less & 23 \\
\hline & & & Save less & 17 \\
\hline & & & No idea & 6 \\
\hline & & & Family help & 1 \\
\hline & & & Worry & 1 \\
\hline & & & 'Die' & 1 \\
\hline & Spend it & 71 & Spend less & 49 \\
\hline & & & Save less & 2 \\
\hline & & & No idea & 8 \\
\hline & & & Family help & 4 \\
\hline & & & Worry & 3 \\
\hline & & & 'Die’ & 1 \\
\hline & & & Less giving & 1 \\
\hline & & & Work & 2 \\
\hline
\end{tabular}

increased to R500 per month for 1999. Only 21 of the 113 in the sample who disclosed their incomes had pensions in this range, with the rest ranging up to a reported R45,000 per month. A number of poorer pensioners appeared, however, to be in subsidised accommodation, which was not reflected in their stated income.

One question, intended to ascertain their propensity to assume risk, asked pensioners what they would do if they had income of an extra R100 per month, and if they had R100 less per month. The answers can be tabulated as shown in Table 1.

One would expect most people to be in a category where they would either treat the extra R100 in the same way as the loss: either save/reduce saving, or spend/reduce spending. This is the case for the biggest group, of 49 people, who would adjust their spending according to their income level. Another 17 would save or reduce saving, and another one would either give more or less.

Over a third, however, appear to find themselves at discontinuities, or points of inflexion, in their utility curves. Twenty three would save any additional money they were given, and a further nine would give it away, but both groups would cut back on spending if they had less money. Another 29 appeared to be at other discontinuities, with two saying they would die if they had anything less than they currently enjoyed.

These discontinuities appear to illustrate the concept of 'hysteresis', which is that the loss of money appears to be worth more than any gain. It is not necessarily a failure of logical thinking. Many of the interviewees appear to have been concerned that they would have to make significant changes to their current circumstances if their wealth (as future income can be described) was to fall by even a relatively small amount. These changes would cause more difficulty than indicated merely by the loss of a little wealth. The problem is that items of expenditure come in discrete 'lumps'. In four cases, for instance, interviewees feared losing their accommodation, which could clearly be particularly painful and disruptive of their existing lifestyles.

On the other hand, a number of 
pensioners made it clear, in the interviews, that additional money was of little concern to them. Statements of this sort were made not only by those who would give the extra money away, but also by a number who said they would save the money. Although the State pensioners were barely above the breadline, about half said they would save extra money - which suggested that even they were not desperate about money. Seven (out of 19 State pensioners) did, however, express serious concerns about their health and accommodation if their incomes were reduced.

Perhaps all that can be concluded is that pensioners' needs do differ, but a majority may be less risk averse than generally supposed, so to sum up:

- most pensioners are happy to spend whatever income they have as a pension

- a significant minority would not want change their current standard of livings, even if they had additional income

- a smaller minority is particularly concerned about what they would do if they had less money on which to live.

It requires little imagination to accept that the state old age assistance plays a critical role - especially for this last group - maintaining an income floor for pensioners.

The consequences for the investment of pensioners money appears to be that, given this floor, most pensioners would be happy to take some risks to increase their incomes. There are, however, some who are both strongly averse to taking additional risks, and who are not particularly interested in additional returns. Active members can, presumably, be divided into similar groups.

\section{Bounded rationality}

These results are clearly only indicative of members' risk aversion, but it is to be doubted whether further research is likely to produce any more definite results.

It appears that most studies that have tried to establish peoples' utility functions have found that people are seldom in a position to give consistent and intelligent instructions as to how to balance risk against return. Kahneman and Tversky, ${ }^{2}$ and Dahlbac ${ }^{3}$ give a number of examples of such attempts to measure people's utility functions, which have rather unearthed logical inconsistencies.

The point is that people find the world too complex to be able to function perfectly rationally at all times. They therefore use what H. A. Simon calls a "bounded nationality — that works most of the time. In many instances this takes the form of heuristics (rules of thumb). 'Neither a borrower nor a lender be', and 'equities are best in the long term', are two that apply to investments.

There is, however, no obvious heuristic that can be applied to those who want to reduce their risks. As discussed above, there are no really low-risk investments available to South African retirement fund members.

What is apparent is that diversification into different assets, the returns from which are not perfectly correlated, will reduce risk. One useful rule of thumb is, therefore, to create diversification.

\section{Investment in equities}

\section{The equity premium puzzle}

This rule provides little help in determining the proportion of a portfolio to invest in each different class of assets.

The problems are that the distribution of future risks and returns is unknowable even if it were possible to construct 
utility curves to trade them off rationally against each other. This can also be described as a question of bounded rationality, because we do not know everything, and can often not process even what we do know.

Most theoretical work overcomes this problem by modelling the future using past data. This work requires the most intimidating mathematics, but the truth is that history seldom repeats itself. It needs some emphasis that, in the midst of the investment community's current infatuation with the mathematics of finance, historical relationships may not apply in future.

In fact, existing economic theory fails to provide an adequate explanation for the key question of investing for retirement: what Siegel and Thaler ${ }^{4}$ call the 'equity premium puzzle'. Investment in shares has given - in any 20-year period in this century - a higher return for lower risk than any alternative investment. This conflicts with the theory that holds that greater returns can only be gained by higher risks and so constitutes a puzzle. The most plausible explanation they find is that investors are myopic and look at risks and returns predominantly over a one-year period.

The equity premium may be significant: it is variously estimated at up to 6 per cent p.a. more than fixed interest investments. A mere 1 per cent p.a. increase in investment earnings over a working lifetime can increase retirement income by 20 per cent. If the equity premium were to continue in future, it would seem that those with a future life expectancy of 20 years or more should invest their pension money almost entirely in equities. For middle income South Africans, this would apply to men under the age of 55, and women under 60 .

But can one rely on the equity premium for one's retirement, especially in South Africa where state assistance represents about 10 per cent of the average wage? There are a number of reasons why it may not continue into the future.

One reason for the equity premium before 1989 - in South Africa - was that pension funds were required to invest 53 per cent of the book value of their assets in fixed interest securities (33 per cent for provident funds and insurers). There is little evidence of equity outperformance subsequently as equities, gilts and cash have yielded very similar returns before tax. It may be that governments around the world have, in the past, used persuasion - explicit or subtle - to keep fixed interest rates at less than their market level. Globalisation will make this less feasible in future.

A more worrying possibility can be built on Wilkie's ${ }^{5}$ insight that much of the superior return over the past 30 years has come from a re-rating of share prices that is unlikely to be repeated. Siegel and Thaler ${ }^{4}$ how that the excess return goes back to the early 19th century, but it must be remembered that in earlier times shares were held largely by company managers and by individuals active in the management of their own portfolios. A large portion of the return should, therefore, be seen as a reward for their skills and entrepreneurial activity. The ownership of shares has largely changed over the last few decades, with retirement funds and other institutions accounting for the majority of ownership in most of the English speaking world. It is difficult to see how retirement funds can ensure they make excessive returns on their share investments when they have no entrepreneurial skills to offer.

Yet another possibility is that greater insight into investment markets will alter the myopia found by Siegel and Thaler. ${ }^{4}$ What is interesting about the published findings is that there is evidence of mean reversion in share prices. This suggests 
that markets tend to overreact to both good and bad news, and in correcting one error may make the opposite. It also means that price changes tend to cancel themselves out in the long run by more than would be expected if they were statistically independent of each other. This may explain why the risk (measured by the volatility) over 20 years is less on equities (which are perhaps more subject to fads) than fixed interest investments.

We are, therefore, again thrown back on rules of thumb. The South African Financial Services Board's prudential investment guidelines, which, inter alia, place a maximum of 75 per cent on equity and property and 15 per cent on overseas holdings, have created something of a consensus in South Africa as to the proportions to be invested in each asset class. The equity portions have, necessarily, fallen with the South African stock market's underperformance over the last few years.

\section{Fewer equities for older members?}

This should not necessarily apply to all funds. It is argued that equities are more volatile in the short run so the proportion of assets in shares should reduce as people get older and investment horizons shorten. Relatively mature retirement funds (with a larger number of older members and pensioners) are expected to have a lower proportion of equities, but trustees and investment managers appear reluctant to follow this suggestion. Their view would be correct if the equity premium is such as to justify higher proportions (than average) in equity for all investors with an investment horizon of longer than a year. Few mortality tables will produce life expectancies of less than a year for anyone under 100 .

This obviously applies to moneys that are required to provide pensions, but a proportion of retirement fund money is required at retirement to repay debt or for the purchase of a house. Low income earners, who will be largely dependent on the State old age pension, may be wise to spend the entire lump sum from their provident fund on housing which is not counted for the means test. There is, however, no asset class available to retirement funds that is correlated to house prices, so there is at this stage no suitable low-risk investment to replace equities. Debt repayment can, however, be matched by cash investments in the retirement fund, and some funds do lend directly to members at an interest rate credited directly to their individual accounts.

Another reason for limiting equity investment by older members is that much of the risk in share investments comes not from ordinary volatility, but from the bursting of unrealistic share price bubbles caused by investment markets overreacting. It is these that ought to be avoided, particularly by older members who have less in the way of opportunity to make up any sharp drop in prices. The bubbles can be recognised by rapid increases in share prices, historically low dividend yields and high ratios of price to earnings and book value.

Older members and mature funds particularly should, under these circumstances, reduce their equity exposure. It would seem that significant investment in American and European share markets should, therefore, be avoided at this time by older investors with limited other assets. This is somewhat unfortunate for South African investors who have only recently been able to invest overseas. They, however, have also enjoyed enough from equity outperformance to enjoy greater retirement incomes than they had reason to expect when they began working. 
The Japanese share price collapse of the 90 s gives a clear illustration of the reality and the consequences of share market bubbles.

Of course, current market levels may not be a bubble but represent a reasonable discounted value of future profits. This possibility makes it difficult for any investment managers to recommend equity investment proportions lower than their competitors. There are, however, some South African retirement funds that are entirely invested in cash - as a result of the extremely bearish views of their trustees. Of course, if one believes shares are overvalued, then both young and old investors would do well to sell them.

This uncertainty as to the equity premium may help explain another puzzle of theoretical economics. ${ }^{6}$ Theory suggests that the proportions of a portfolio invested in equities and long term fixed interest investments should remain in the same ratio regardless of the investors' risk aversion. (More risk-averse investors are meant to invest more in cash.) The puzzle is that most investment advisors recommend a higher allocation to fixed interest investments for more risk-averse individuals. Perhaps, by risk averse, the investment advisors have in mind investors with a more jaundiced view of equities.

\section{The consequences}

This is, and probably always will be, an imponderable question: the brightest economic minds are baffled. Is there any real merit in asking individual members to make the decisions?

\section{The providers' wants}

The move to offer members investment choice does, however, require some explanation. The most likely would appear to be investment managers' eagerness to increase their fees. The escalation of investment management fees over the last decade is difficult to explain. The lowest charges available for large retirement funds have risen from some 0.25 per cent to about 0.4 per cent for local investment. The charges for unit trust investment have risen from 0.5 per cent to 1.14 per cent and higher.

Salaries in this sector have certainly risen faster than inflation, but the biggest inflation has derived from increased profit margins. Evaluating the quality of the service provided could be the subject of a paper on its own, but this author is unaware of any evidence of improvements.

It is, however, easy to see how trustees can be persuaded to pay more for investment management. It is clearly incumbent on them to use the 'best' investment manager available. The investment managers employ bright, well-educated, articulate young investment managers whose obvious wealth and confidence make them persuasive salespeople. They find it relatively easy to persuade groups of trustees that their employer's past outperformance will continue in future - and more than pay the additional charges. The fact is that, even if some managers are better than others (and this itself is highly unlikely), the time and expertise necessary for evaluation are beyond many trustee' ability.

O'Barr and Conley ${ }^{7}$ - in a careful two-year study of the culture and behaviour of nine large pension funds in the USA - confirm the author's experience of 'surprising and sometimes' disturbing evidence of 'an unsystematic approach' to investment decisions. They observed that relationships are often more important than managing the bottom line in evaluating and deciding whether to retain managers'. As 
anthropologists they welcomed the recognition of the human element in circumstances where significant objective measures were hard to obtain - but also recorded their feelings that, in the situations they had observed, 'the balance had tipped too far'. In this they seem little different from South African funds.

It appears to this author that the offering of investment choice is part of this general trend to increase investment charges, and is pursued by consultants and investment managers for this reason.

\section{The investment experts}

A minority of members clearly do want to have control over their investments, for various reasons: either to reduce their exposure to equities, avail themselves of the benefits of insurance company guarantees, or choose a particular investment manager.

That they are a minority is confirmed by SANLAM's ${ }^{8}$ finding that: 'only about $20 \%$ to $30 \%$ of the members respond to the offer to switch portfolios and many of them make minor or no changes'. This minority is likely to be better educated and represented on the board of trustees of a fund. An idea of its size can be determined by looking at the number of readers of South Africa's financial weeklies. The total circulation is less than 100,000. Readership may be three times this number, but even then would amount to little more than 5 per cent of the membership of South African retirement funds. Ninety five per cent of fund membership have little interest in the technicalities of investment.

The 5 per cent that are interested will, in most cases, have assets other than those held in their retirement funds. These can be used, relatively inexpensively, to adjust the overall level of risk in their portfolios - if necessary using derivative instruments. They are, therefore, not greatly inconvenienced by not having any investment choice in their fund. Insurance company guarantees can likewise be largely replicated through derivatives.

If there are members of the fund who have a real expertise in choosing investment managers, it would seem that trustees would be advised to utilize such ability by setting up an investment advisory committee. For reasons set out earlier, however, it is more likely that passing on the choice of investment managers to the members will create more costs than benefits.

\section{Individual investment choice}

The main argument for investment choice is that, because members have different appetites for risk, they should be given the choice of portfolios with different risk profiles. Another is that, because their portfolios are directly affected, they should be given the choice of investment manager.

These arguments are largely empty. It has been argued above that, whatever their risk aversion, retirement fund members require more or less the same mix of assets. The most important question is the future risk adjusted return on equities and on this even the experts are deeply divided.

On the other hand, it would be extremely surprising if members were more able to identify good investment managers than the trustees. As the literature is full of examples of good performance relative to the market in one period being followed by poor performance in the next, poorly-informed members are more likely to make the mistake of following the best performance than trustees.

The extra charges that must be made for administering and advising members on individual choice, therefore, add no 
value. On the contrary, they place an unnecessary burden of investigation and decision making on members.

\section{Conclusion}

Retirement funds offer employed people a safe and efficient way of managing most of their life insurance and investment needs. Offering members investment choices loads them with additional expenses and concerns about which they can effectively do nothing.

\section{References}

1 Andrew, J. P. (1994) 'Risk Management in a Defined Contribution Scheme', Transactions of the
Actuarial Society of South Africa X(II): pp. 348-420.

2 Kahneman, D. and Tversky, A. (1984) 'Choices, Values and Frames', American Psychologist 39: pp. 341-50.

3 Dahlback, O. (1990) 'An Experimental Analysis of Risk Taking', Theory and Decision 29, pp. 183-202.

4 Siegel, J. J. and Thaler, R. H. (1997) 'The Equity Premium Puzzle,' Journal of Economic Perspectives 11.1, pp. 191-200.

5 Wilkie, A. D. (1998) 'Decomposing the Returns on Ordinary Shares', Transactions of the 26th International Congress of Actuaries 7: pp. 107-120.

6 Canner, N., Mankiw, N. G. and Weil, D. N. (1977) 'An Asset Allocation Puzzle', American Economic Review 87: pp. 181-191.

7 O'Barr, W. M and Conley, J. M. (1992) 'Fortune and Folly: the Wealth and Power of Institutional Investing', Business One Irwin, Homewood, Illinois.

8 SANLAM (1998) 'Retirement Benefits in South Africa', The Liaison Officer, Employee Benefits, PO Box 1 SANLAMHOF 